33 Cooper C, Mukadam N, Katona C, Lyketsos CG, Blazer D, Livingston G, et al Systematic review of the effectiveness of pharmacologic interventions to improve quality of life and well-being in people with dementia. Am J Geriatr Psychiatry 2013; 21: 173-80.

34 Cooper C, Mukadam M, Katona C, Lyketsos C, Ames D, Livingston G, et al. Systematic review of the effectiveness of non-pharmacological interventions to improve quality of life of people with dementia. Int Psychogeriatr 2012; 24: 856-70.

35 Selwood A, Thorgrimsen L, Orrell M. Quality of life in dementia-a one-year follow-up study. Int J Geriat Psychiatry 2005; 20: 232-7.

36 Lyketsos CG, Gonzales-Salvador T, Chin J, Baker A, Black B, Rabins P. A follow-up study of change in quality of life among persons with dementia residing in a long-term care facility. Int J Geriat Psychiatry 2003; 18: 275-81.

37 Missotten $\mathrm{P}$, Ylieff M, Di Notte D, Paquay L, De Lepeleire J, Fontaine O. Quality of life in dementia: a 2-year follow-up study. Int J Geriat Psychiatry 2007; 22: 1201-7.

38 Orrell M, Yates L, Burns A, Russell I, Woods RT, Hoare Z, et al. Individual Cognitive Stimulation Therapy for Dementia (iCST Trial). Trials 2012; 13: 172

39 National Institute for Health and Clinical Excellence and the Social Care Institute for Excellence (NICE-SCIE). Dementia: Supporting People with Dementia and their Carers in Health and Social Care. Clinical Guideline 42. NICE and SCIE, 2007.

\title{
Wilfred Owen
}

Bent double, like old beggars under sacks,

knock-kneed, coughing like hags, we cursed through sludge,

Till on the haunting flares we turned our backs,

And towards our distant rest began to trudge.

Men marched asleep. Many had lost their boots,

But limped on, blood-shod. All went lame, all blind

Drunk with fatigue; deaf even to the hoots

of gas-shells dropping softly behind.

Gas! Gas! Quick boys! - An ecstasy of fumbling, Fitting the clumsy helmets just in time,

But someone still was yelling out and stumbling And floundering like a man in fire or lime. -

Dim through the misty panes and thick green light, As under a green sea, I saw him drowning. In all my dreams, before my helpless sight, He plunges at me, guttering, choking, drowning.

If in some smothering dreams, you too could pace Behind the wagon that we flung him in, And watch the white eyes writhing in his face,

His hanging face, like a devil's sick of sin; If you could hear, at every jolt, the blood come gargling from the froth-corrupted lungs,

Obscene as cancer, bitter as the cud Of vile, incurable sores on innocent tongues, My friend, you would not tell with such high zest To children ardent for some desperate glory, The old Lie: Dulce et decorum est

Pro patria mori.

Selected by Femi Oyebode. 